\title{
INFLUENCE OF WOOD STACKING LOCATION ON FOREST TRANSPORT COSTS
}

\author{
Danilo Lopes Fernandes ${ }^{1}$, Lisandra Maria Alves Matos ${ }^{2 *}$, Emanuelly Canabrava Magalhães ${ }^{3}$, Christian Dias \\ Cabacinha $^{4}$, Adriana Leandra de Assis ${ }^{5}$, Carlos Alberto Araújo Júnior ${ }^{6}$

\begin{abstract}
${ }^{1}$ Universidade Federal de Minas Gerais, Forest Engineering Course, Montes Claros, Minas Gerais, Brazil - csdanilofernandes@ gmail.com ${ }^{2 *}$ Federal University of Paraná, Graduate Program, Curitiba, Paraná, Brazil - lisandraamatos@ gmail.com

${ }^{3}$ Federal University of Minas Gerais, Forest Engineering Course, Montes Claros, Minas Gerais, Brazil - emanuellymagalhaes1@ gmail.com

${ }^{4}$ Federal University of Minas Gerais, Forest Sciences Department, Montes Claros, Minas Gerais, Brazil - christiancabacinha@ gmail.com

${ }^{5}$ Federal University of Minas Gerais, Forest Sciences Department, Montes Claros, Minas Gerais, Brazil - alassis@ufmg.br

${ }^{6}$ Federal University of Minas Gerais, Forest Sciences Department, Montes Claros, Minas Gerais, Brazil - araujocaj@gmail.com
\end{abstract}

Received for publication: 14/08/2018 - Accepted for publication: 06/06/2019

\begin{abstract}
Resumo
Influência da localização das pilhas de madeira nos custos de transporte florestal rodoviário. Destacada a importância do planejamento do transporte florestal rodoviário por sua alta participação no custo final da madeira, a distância entre talhões de plantios florestais e o destino final deve ser otimizada de forma que reduza o custo do processo. É conhecida a relação entre a distância e o custo do transporte, contudo ainda é necessário avaliar o quanto o posicionamento das pilhas de madeira dentro do talhão interfere nesse custo. Dessa forma, procurou-se avaliar a influência do local de empilhamento de madeira nos custos do transporte florestal rodoviário. Com a utilização do software QGIS, foi realizada a vetorização do mapa geral de uma propriedade localizada no estado de Minas Gerais, sendo as áreas de plantio representadas por polígonos, as estradas de acesso interno e externo representadas por linhas e os possíveis locais de empilhamento da madeira a ser transportada sendo representados por pontos. Em cada talhão foram considerados quatro locais para empilhamento da madeira, sendo cada um deles em uma de suas faces. Considerando isso, foram realizadas simulações de rotas ótimas baseadas no critério da menor distância entre cada pilha de madeira e uma planta de carbonização. Os resultados apontaram uma redução de $32 \%$ no custo final do transporte quando se optou pelo empilhamento da madeira nos locais mais próximos da planta de carbonização. Assim, pode-se afirmar que a escolha do ponto ideal de empilhamento, sob o aspecto da maior proximidade ao local de destino do transporte de madeira, pode gerar economia neste processo.
\end{abstract}

Palavras-chave: planejamento florestal; geoprocessamento.

Given the importance of forest transportation planning due to its high contribution in wood final cost, the distance between forest plantation stands and the wood final destination should be optimized in order to reduce process cost. The relation between distance and transportation cost is known, yet, it is still necessary to evaluate how much the location of the wood piles inside the stand interferes with its final cost. Thus, we try to evaluate the influence of the wood stacking location on forest transportation costs. The vectorization of the general map of a property located in Minas Gerais state was performed through the QGIS software, by representing the planting areas by polygons, internal and external access roads by lines, and the possible wood-stacking location to be transported by points. In each stand, four wood-stacking sites were considered, each on one side of the stand. Considering this, optimal route simulations were performed based on the criterion of the shortest distance between each pile of wood and a carbonization plant. The results showed a $32 \%$ reduction in the final cost of transportation when the wood is stacked in places closer to the carbonization plant. Therefore, the results evidence that the choice of the ideal stacking point, in the aspect of closer proximity to the destination of the wood transportation, can generate savings in this process.

Keywords: forest planning; geoprocessing.

\section{INTRODUCTION}

Computational tools that became easier for the decision-making process in the forest sector have become important. They can generate alternatives to optimize the production process and reduce operational costs. They can also be applied to road transportation of logs, which has a big contribution to the costs of wood delivered to the consumers (LIMA et al., 2011). This forest operation is affected by factors, such as the simple definition of the place to locate pile logs around stands.

Select places to locate the processing units and the forest plantations require strategic decisions and complex planning. These choices can turn infeasible the investments when supply locations are far from the consumers (LACHINI et al., 2018; FRISK et al., 2010). Thus, many studies about the maximum feasible distance

FLORESTA, Curitiba, PR, v. 50, n. 1, p. 1047 - 1052, jan/mar 2020.

Fernandes, D. L. et.al.

ISSN eletrônico 1982-4688 
for log transportation have been published. This occurs because costs range directly with the distance and the forest road transportation is responsible for almost $85 \%$ of transported wood in Brazil (SILVA et al., 2007).

Other factors are the increasing competitiveness between industries and the claim about a high-quality pattern for supply wood. These aspects are fundamental for the development of studies about the decision-making process in forest companies, always focusing on different optimization tools. Their main aims are to reduce forest transportation costs and maintain the mills provided of wood (CARDOSO; OLIVEIRA; JOAQUIM JUNIOR, 2016).

Two difficulties Silva et al. (2009) pointed out regarding forest road transportation are the large pool of decision variables (alternatives) and the lack of techniques that support the decision-making. The former persists until nowadays and has increased due to demands of a better understanding of forest activities planning. The latter can be considered as unrealistic mainly because there are management tools for forest operations, for instance, geoprocessing, linear programming, and artificial intelligence. These tools have been applied in order to schedule the harvest and transportation operations, to know better the forest and to analyze the interaction between forest activities (LIMA et al., 2011; SILVA et al., 2016).

Among the tools used in forest planning, Geographic Information Systems (GIS) makes the decisionmaking process more efficient. GIS has been deemed important in planning harvest and skidding logs and the determining of optimal routes for forest road transport. The tool has produced interesting reports and allowed reduction of costs (LIMA et al., 2011). Examples of scientific works that use GIS in the forest sector are Silva et al. (2016), Ko et al. (2019), and Duka et al. (2017).

Considering the importance of forest road transportation in the total cost of delivered wood, this study aimed to evaluate the impact of the location of wood piles in the forest transportation costs.

\section{MATERIAL AND METHODS}

The area under study is a plantation of Eucalyptus sp. located in the north region of Minas Gerais State, focused on the production of charcoal. Sixteen stands, around 7 years-old, were accounted for, totaling 363.39 ha of a plan area (Table 1). Mapping was done with the Qgis software, v. 2.14. A vector layer from a polygon type represented stands and a vector layer from a line type represented roads.

Tabela 1. Dados do inventário florestal pré-corte do plantio florestal.

Table 1. Pre-harvest inventory of the forest plantation.

\begin{tabular}{|c|c|c|c|c|c|}
\hline Stand & Area (ha) & Volume $\left(\mathrm{m}^{3} / \mathrm{ha}\right)$ & Stand & Area (ha) & Volume $\left(\mathrm{m}^{3} / \mathrm{ha}\right)$ \\
\hline $\mathrm{T}-01$ & $12, .10$ & 200.33 & T-09 & 25.79 & 279.60 \\
\hline $\mathrm{T}-02$ & 21.88 & 263.50 & $\mathrm{~T}-10$ & 16.64 & 230.30 \\
\hline $\mathrm{T}-03$ & 16.19 & 212.93 & $\mathrm{~T}-11$ & 27.53 & 235.83 \\
\hline $\mathrm{T}-04$ & 24.76 & 259.30 & $\mathrm{~T}-12$ & 20.05 & 209.51 \\
\hline $\mathrm{T}-05$ & 16.45 & 286.38 & $\mathrm{~T}-13$ & 29.02 & 235.06 \\
\hline $\mathrm{T}-06$ & 31.37 & 213.61 & $\mathrm{~T}-14$ & 20.83 & 168.58 \\
\hline $\mathrm{T}-07$ & 36.74 & 272.63 & $\mathrm{~T}-15$ & 26.42 & 265.66 \\
\hline $\mathrm{T}-08$ & 24.35 & 233.00 & $\mathrm{~T}-16$ & 13.27 & 247.57 \\
\hline
\end{tabular}

Freight price was fixed at $\mathrm{R} \$ 10,00$ per kilometer considering a Bitrem truck with $19.8 \mathrm{~m}$ length, 57 ton combined total weight, and $57 \mathrm{~m}^{3}$ wood capacity. For each stand, the central point of each face (north, south, east and west) was considered as a reference for the location of wood piles. These places were represented in GIS as a point vector layer (Figure 1).

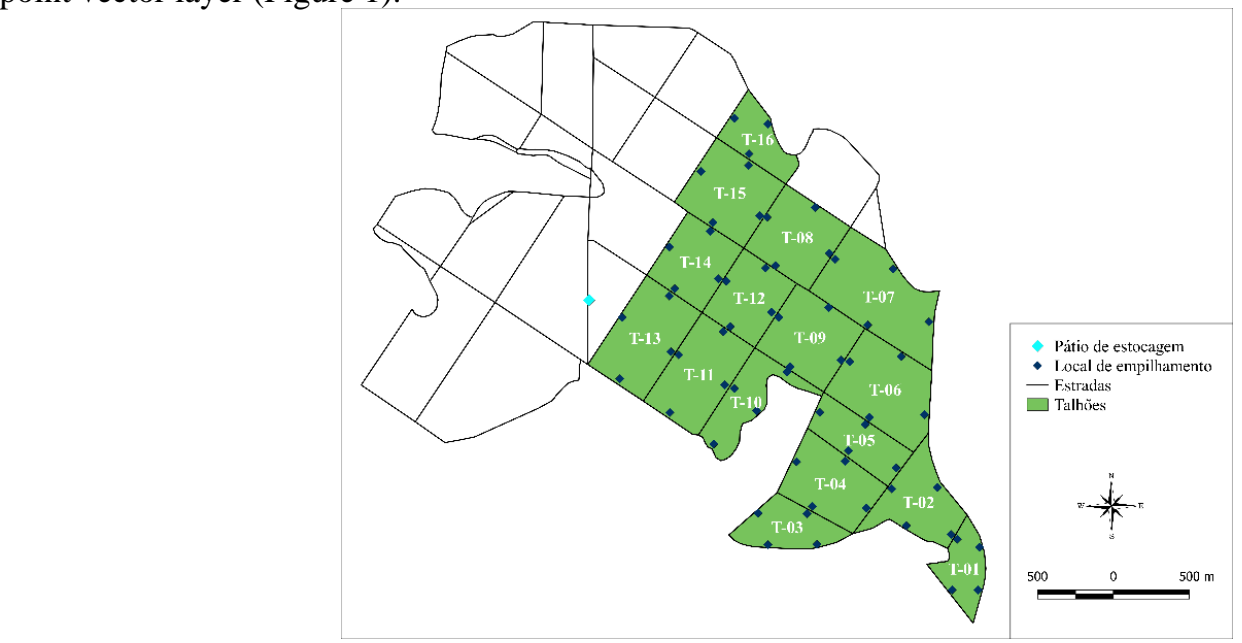


Figura 1. Croqui da área de estudo.

Figure 1. Study area sketch.

Real shortest distances (optimal routes) between wood yard and wood piles in stands were calculated using the v.net.distance algorithm in the QGIS software. Thus, four routes for each stand were generated, one for each stand face. The shortest and the longest one for each stand was considered. Silva et al. (2007) equation was used to estimate wood transportation costs:

$$
C T=\frac{P f}{C a p} * 2 D * P
$$

where: $C T=$ transportation cost $(\mathrm{R} \$) ; P f=$ freight price $(\mathrm{R} \$ / \mathrm{km}) ; C a p=$ truck capacity $\left(\mathrm{m}^{3}\right) ; D=$ distance from wood pile to wood yard $(\mathrm{km})$; and $P=$ amount of wood in stand $\left(\mathrm{m}^{3}\right)$.

The differences between the shortest and the longest routes (DD) for each stand were calculated. The existence of a trend or correlation between DD and stand area was evaluated. For this, a scatter plot was drafted with a later linear equation adjustment considering DD as the dependent variable and stand area as an independent variable. Finally, a simulation was done increasing the value of DD and calculating its effect on the transportation total cost.

\section{RESULTS}

It was possible to determine the shortest path between wood yard and all wood piles in stand boundaries. The paths with minimum distance from each stand were calculated (Figure 2).



Figura 2. Ilustração das rotas saindo do pátio de estocagem e chegando aos locais de empilhamento escolhidos em cada talhão.

Figure 2. Illustration of the routes coming from the wood yard and arriving at the stacking sites chosen in each stand.

The average distance considering the shortest paths was $2.10 \pm 0.89 \mathrm{~km}$ (Table 2). The one considering the longest paths was $2.73 \pm 0.94 \mathrm{~km}$. The average difference between both routes was $0.63 \pm 0.14 \mathrm{~km}$.

Tabela 2. Maior e menor distância de cada talhão até a planta de carbonização e custo total de transporte, por talhão, considerando a menor e a maior distância de transporte da madeira.

Table 2. The highest and shortest distance from each stand to the carbonization plant and total transportation cost, by stand, considering the shortest and longest distance of the wood transportation.

\begin{tabular}{|c|c|c|c|c|c|c|c|}
\hline \multirow{2}{*}{ Stand } & \multicolumn{3}{|c|}{ Distance $(\mathrm{km})$} & \multirow{2}{*}{$\begin{array}{c}\text { Volume } \\
\left(\mathrm{m}^{3}\right)\end{array}$} & \multicolumn{3}{|c|}{ Cost per distance $(\mathrm{R} \$)$} \\
\hline & Shortest & Longest & Difference & & Shortest & Longest & Difference \\
\hline $\mathrm{T}-01$ & 3.89 & 4.45 & 0.56 & $2,423.99$ & $3,312.42$ & $3,786.44$ & 474.02 \\
\hline $\mathrm{T}-02$ & 3.15 & 3.91 & 0.76 & $5,765.38$ & $6,385.15$ & $7,924.06$ & $1,538.91$ \\
\hline $\mathrm{T}-03$ & 3.15 & 3.79 & 0.64 & $3,447.34$ & $3,818.10$ & $4,585.05$ & 766.95 \\
\hline
\end{tabular}

FLORESTA, Curitiba, PR, v. 50, n. 1, p. 1047 - 1052, jan/mar 2020.

Fernandes, D. L. et.al.

ISSN eletrônico 1982-4688 


\begin{tabular}{rrrrrrrr} 
T-04 & 2.73 & 3.36 & 0.63 & $6,420.27$ & $6,162.31$ & $7,570.37$ & $1,408.06$ \\
T-05 & 2.37 & 3.11 & 0.74 & $4,710.95$ & $3,932.62$ & $5,142.42$ & $1,209.80$ \\
T-06 & 2.49 & 3.23 & 0.74 & $6,700.95$ & $5,874.73$ & $7,604.96$ & $1,730.23$ \\
T-07 & 2.55 & 3.57 & 1.02 & $10,016.43$ & $8,979.53$ & $12,563.48$ & $3,583.95$ \\
T-08 & 2.01 & 2.56 & 0.55 & $5,673.55$ & $4,012.27$ & $5,116.13$ & $1,103.86$ \\
T-09 & 1.95 & 2.47 & 0.52 & $7,210.88$ & $4,950.23$ & $6,267.73$ & $1,317.50$ \\
T-10 & 1.42 & 1.96 & 0.54 & $3,832.19$ & $1,917.21$ & $2,645.88$ & 728.67 \\
T-11 & 1.04 & 1.66 & 0.62 & $6,492.40$ & $2,389.95$ & $3,788.35$ & $1,398.40$ \\
T-12 & 1.48 & 1.97 & 0.49 & $4,200.68$ & $2,195.88$ & $2,909.18$ & 713.30 \\
T-13 & 0.65 & 1.23 & 0.58 & $6,821.44$ & $1,561.73$ & $2,952.46$ & $1,390.73$ \\
T-14 & 1.05 & 1.53 & 0.48 & $3,511.52$ & $1,293.87$ & $1,892.83$ & 598.96 \\
T-15 & 1.52 & 2.23 & 0.71 & $7,018.74$ & $3,747.81$ & $5,498.48$ & $1,750.67$ \\
T-16 & 2.12 & 2.61 & 0.49 & $3,285.25$ & $2,449.65$ & $3,017.23$ & 567.58 \\
Average & 2.10 & 2.73 & 0.63 & $5,470.75$ & $3,936.47$ & $5,204.07$ & $1,267.60$ \\
\hline
\end{tabular}

When the values of the difference between the shortest and the longest routes were correlated with the stands area size, Pearson correlation ( $\mathrm{r}$ ) was $57,78 \%$. This result shows that there is a trend indicating that when the stand area increases, the difference between the mentioned routes became larger (Figure 3).

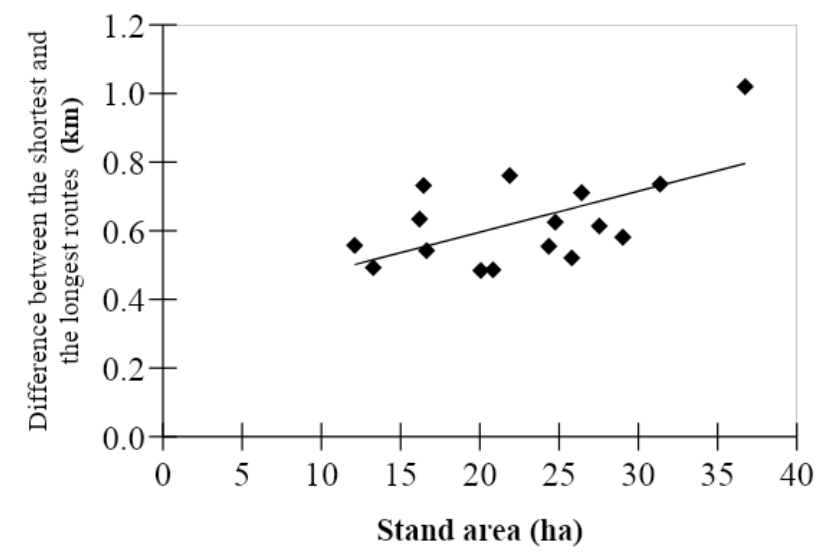

Figura 3. Comportamento da relação entre a área do talhão e a diferença entre a menor e maior distância de transporte da madeira.

Figure 3. Relationship behavior between the stand area and the difference between the shortest and longest distance of wood transportation.

The highest transportation costs for both routes considered for each stand were obtained for stand T-07 (Table 2). These values were more influenced by volumetric production than the distance between wood source and destination. Stand T-14 has the spotlight in regards to the lowest costs. Its transportation cost value also was more influenced by the amount of available wood than by transportation distance.

The total transportation cost for all stands was $\mathrm{R} \$ 62,983.92$ when the shortest transportation distances are considered. The value increases to $\mathrm{R} \$ 83,265.07$ when for longest transportation distance. This corresponds to an increase of $\mathrm{R} \$ 0.23$ per cubic meter of transported wood.

An increase in the variation of the transportation cost was observed when the difference between the shortest and the longest routes by stand increases. This shows that these variables are directly proportional (Table $3)$. 
Tabela 3. Variação no custo de transporte (por hectare) a partir da variação na diferença entre as distâncias.

Table 3. Variation on the transportation cost (per hectare) in relation to the variation of the difference between the distances.

\begin{tabular}{ccccccc}
\hline $\begin{array}{c}\text { Increase of the } \\
\text { difference between } \\
\text { distances }\end{array}$ & $\begin{array}{c}\text { Simulated cost } \\
\text { per hectare }\end{array}$ & $\begin{array}{c}\text { Ranging in } \\
\text { cost per } \\
\text { hectare }\end{array}$ & & $\begin{array}{c}\text { Increase of the } \\
\text { difference between } \\
\text { distances }\end{array}$ & $\begin{array}{c}\text { Simulated cost } \\
\text { per hectare }\end{array}$ & $\begin{array}{c}\text { Ranging in } \\
\text { cost per } \\
\text { hectare }\end{array}$ \\
\hline $10 \%$ & $\mathrm{R} \$ 18231$ & $3.56 \%$ & & $110 \%$ & $\mathrm{R} \$ 235.58$ & $39,18 \%$ \\
$20 \%$ & $\mathrm{R} \$ 187.63$ & $7.12 \%$ & & $120 \%$ & $\mathrm{R} \$ 240.90$ & $42,74 \%$ \\
$30 \%$ & $\mathrm{R} \$ 192.96$ & $10.68 \%$ & & $130 \%$ & $\mathrm{R} \$ 246.23$ & $46,30 \%$ \\
$40 \%$ & $\mathrm{R} \$ 198.29$ & $14.25 \%$ & & $140 \%$ & $\mathrm{R} \$ 251.56$ & $49,86 \%$ \\
$50 \%$ & $\mathrm{R} \$ 203.61$ & $17.81 \%$ & & $150 \%$ & $\mathrm{R} \$ 256.88$ & $53,42 \%$ \\
$60 \%$ & $\mathrm{R} \$ 208.94$ & $21.37 \%$ & & $160 \%$ & $\mathrm{R} \$ 262.21$ & $56,98 \%$ \\
$70 \%$ & $\mathrm{R} \$ 214.27$ & $24.93 \%$ & & $170 \%$ & $\mathrm{R} \$ 267.54$ & $60,54 \%$ \\
$80 \%$ & $\mathrm{R} \$ 219.60$ & $28.49 \%$ & & $180 \%$ & $\mathrm{R} \$ 272.86$ & $64,11 \%$ \\
$90 \%$ & $\mathrm{R} \$ 224.92$ & $32.05 \%$ & & $190 \%$ & $\mathrm{R} \$ 278.19$ & $67,67 \%$ \\
$100 \%$ & $\mathrm{R} \$ 230.25$ & $35.61 \%$ & $200 \%$ & $\mathrm{R} \$ 283.52$ & $71,23 \%$ \\
\hline
\end{tabular}

\section{DISCUSSION}

The wood piles location inside stands can change wood transportation costs. When they are in the shortest face from stand to the wood yard, transportation costs can decrease. Although the differences between the shortest and longest routes were small in most cases, the impact on costs was significant. Since there is a linear relationship between this difference and the stand area, this discrepancy in costs is more important.

Longest routes increase forest transportation costs because of its direct relation to the distance, as observed by Silva et al. (2007). The results show that defining the location of wood piles considering optimal routes for transportation allows a decrease in operational costs. Considering our data, this definition saved $\mathrm{R} \$$ 20,218.96 (32\%) on final transportation costs.

The distance from stands to wood yard also was determinant in other studies, like Holzleitner et al. (2011). In this case, the authors mentioned that the transportation cost can be reduced and the efficiency improved with the decrease of travel time and route optimization. Palander et al. (2013) used a route minimization tool to reduce transportation costs. These examples highlight the need to test different techniques from operational research to allow assertive decision-making by the managers.

Another interesting result is related to the difference between the two routes selected by each stand. It is possible to note that an increase of $10 \%$ in this value increases transportation costs in $18.67 \%$. In other words, when a manager decides to allocate wood piles in a face that demands a long route to the wood yard, there is a gradual increase in the transportation cost. Sometimes this value can be changed by improving the conditions of stacking in the face more indicated for forest transportation.

It is important to highlight that the tool used to determine optimal routes considered the minimum distance as the objective function. However, this option cannot guarantee minimum costs. Besides distance, other factors can cause influence the activity cost (CAVALLI et al., 2010). For instance, the vehicles and their capacities (ALVES et al., 2013), the load and unload time (HARIDASS et al., 2014), the conservation rate of road, pavement type (CHICHORRO et al., 2017) or the lack of training of truck drivers (SILVEIRA et al., 2014). Still, lumbering activities costs also influence the total cost of wood transportation, but they were not considered in this study.

Thus, other routes can be more suitable concerning limiting factors, reducing forest transportation costs. This shows that there are opportunities for new studies aiming to improve current knowledge and optimize this activity. For instance, other techniques such as linear programming (LACOWICZ et al., 2002) and metaheuristics (HARIDASS et al., 2014) can be applied.

\section{CONCLUSION}

- The location of wood piles in the stands exerts an influence on the total cost of road forest transportation. Defining the ideal point of piling considering the minimum distance from the load truck point to the final destination of wood can generate economies in this process.

FLORESTA, Curitiba, PR, v. 50, n. 1, p. 1047 - 1052, jan/mar 2020.

Fernandes, D. L. et.al.

ISSN eletrônico 1982-4688 


\section{REFERENCES}

ALVES, R. T.; FIEDLER, N. C.; SILVA, E. N.; LOPES, E. S.; CARMO, F. C. A. Technical analysis and transportation costs of wood with different type of vehicles. Revista Árvore, v. 37, n. 5, p. 897-904, 2013.

CARDOSO, L. E. Z.; OLIVEIRA, P. P.; JOAQUIM JUNIOR, C. F. Redução de custos no transporte de madeira por meio de roteirização otimizada: um estudo de caso. Tekhne e Logos, v. 7, n. 1, p. 31-46, 2016.

CAVALLI, R.; GRIGOLATO, S. Influence of characteristics and extension of a forest road network on the supply cost of forest woodchips. Journal of Forest Research, v.15, n.3, p.202-209, 2010.

CHICHORRO, J. F.; SILVA, A. L. P.; ANDRADE, W. S. P.; HEGEDUS, C. E. N.; KUBOYAMA, F. A. Q. Custos e índices econômicos de povoamentos de eucalipto do Programa Produtor Florestal no Espírito Santo. Pesquisa Florestal Brasileira, v. 37, n. 92, p.447-456, 2017.

DUKA, A.; GRIGOLATO, S.; PAPA, I.; PENTEK, T.; PORSINSKY, T. Assessment of timber extraction distance and skid road network in steep karst terrain. iForest: Biogeosciences and Forestry, v. 10, n. 6, p. 886-894, 2017.

FRISK, M.; GÖTHE-LUNDGREN, M; JÖRNSTEN, K.; RÖNNQVIST, M. Cost allocation in collaborative forest transportation. European Journal of Operational Research, v. 205, n. 2, p.448-458, set. 2010. Elsevier BV. http://dx.doi.org/10.1016/j.ejor.2010.01.015.

HARIDASS, K.; VALENZUELA, J.; YUCEKAYA, A. D.; MCDONALD, T. Scheduling a log transport system using simulated annealing. Information Sciences, v. 264, n. 1, p. 302-316, 2014.

HOLZLEITNER, F.; KANZIAN, C.; STAMPFER, K. Analyzing time and fuel consumption in road transport of round wood with an onboard ûeet manager. European Journal of Forest Research, v.130, n.2, p.293-301, 2011.

KO, S.; LAUTALA, P.; FAN, J.; SHONNARD, D. R. Economic, social, and environmental cost optimization of biomass transportation: a regional model for transportation analysis in plant location process. Biofuel, bioproducts and biorefining, v. 13, n. 1, p. 582-598, 2019.

LACHINI, E.; FIEDLER, N. C.; SILVA, E. F. DA; VIEIRA, G. C.; SOUZA, L. A. DE; CARMO, F. C. A. DO. Pesquisa operacional na minimização de custos de transporte florestal. Revista Brasileira de Biometria, v. 36, n. 2, p.473-488, 2018.

LACOWICZ, P. G.; BERGER, R.; TIMOFEICZYK JÚNIOR, R.; SILVA, J. C. L. Minimização dos custos de transportes rodoviário florestal com o uso da programação linear e otimização do processo. Floresta, v.32, n.1, p.75-87, 2002.

LIMA, M. P.; CARVALHO, L. M.T.; MARTINHAGO, A. Z.; OLIVEIRA, L. T.; CARVALHO, S. P. C.; DUTRA, G. C.; OLIVEIRA, T. C. A. Methodology for planning log stacking using geotechnology and operations research. Cerne, v. 17, n. 3, p.309-319, 2011.

MACHADO, C. C.; LOPES, E. S. Análise da influência do comprimento de toras de eucalipto na produtividade e custo da colheita e transporte florestal. Cerne, v.6, n.2, p.124-129, 2000.

PALANDER, T.; VÄÄTÄINENB, J.; LAUKKANENB, S.; MALINENB, J. Modeling Backhauling on Finnish Energy-Wood Network Using Minimizing of Empty Routes. International Journal of Forest Engineering, v.15, n.2, p.79-84, 2013.

SILVA, F.; MINETTE, L. J.; SOUZA, A. P.; MORAES, A. C.; SCHETTINO, S. Classification of forest roads and determination of route using geographic information system. Revista Árvore, Viçosa, v.40, n.2, p.329-335, 2016.

SILVA, M. L.; OLIVEIRA, R. J.; VALVERDE, S. R.; MACHADO, C. C.; PIRES, V. A. V. Análise o custo e do raio econômico de transporte de madeira de reflorestamentos para diferentes tipos de veículos. Revista Árvore, Viçosa, v.31, n.6, p. 1073-1079, set. 2007.

SILVA, G. F.; PIASSI, L. C.; MORA, R.; MARTINS, L. T.; TEIXEIRA, A. F.; JUNIOR, A. A. B. Metaheurística algoritmo genético na solução de modelos de planejamento florestal. Revista Brasileira de Ciências Agrárias, Recife, v.4, n.2, p-160-166, 2009.

SILVEIRA, G. L.; MACHADO, C. C.; SOUZA, A. P.; LEITE, H. G.; SANTOS, H. N.; FERNANDES, D. C. M. Avaliação de parâmetros de consumo de combustível do tritrem no transporte de madeira. Revista Árvore, Viçosa, v.28, n.1, p.99-206, 2004. 